\title{
DNA markers linked to yield, yield components, and morphological traits in autotetraploid lucerne (Medicago sativa L.)
}

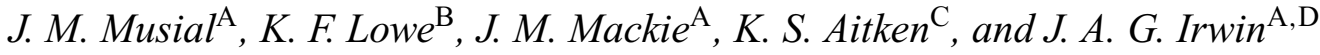

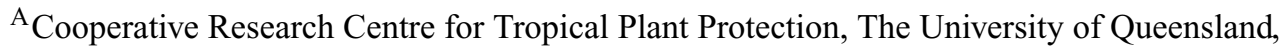 \\ Brisbane, Qld 4072, Australia. \\ ${ }^{B}$ Department of Primary Industries and Fisheries, Mutdapilly Research Station, \\ Peak Crossing, Qld 4306, Australia. \\ ${ }^{\mathrm{C}}$ CSIRO Plant Industry, Queensland Bioscience Precinct, St Lucia, Qld 4067, Australia. \\ DCorresponding author. Email: j.irwin@uq.edu.au
}

\begin{abstract}
We have mapped and identified DNA markers linked to morphology, yield, and yield components of lucerne, using a backcross population derived from winter-active parents. The high-yielding and recurrent parent, $\mathrm{D}$, produced individual markers that accounted for up to $18 \%$ of total yield over 6 harvests, at Gatton, south-eastern Queensland. The same marker, AC/TT8, was consistently identified at each individual harvest, and in individual harvests accounted for up to $26 \%$ of the phenotypic variation for yield. This marker was located in linkage group 2 of the D map, and several other markers positively associated with yield were consistently identified in this linkage group. Similarly, markers negatively associated with yield were consistently identified in the W116 map, W116 being the low-yielding parent. Highly significant positive correlations were observed between total yield and yield for harvests 1-6, and between total yield and stem length, tiller number, leaf yield/plant, leaf yield $/ 5$ stems, stem yield/plant, and stem yield/5 stems. Highly significant QTL were located for all these characters as well as for leaf shape and pubescence.
\end{abstract}

Additional keywords: alfalfa, non-dormant.

\section{Introduction}

Lucerne (Medicago sativa L.) is one of the world's most widely grown forage crops, with an estimated world area of $32 \mathrm{Mha}$ in the 1980s (Michaud et al. 1988). In Australia approximately 200000 ha of lucerne is grown under irrigation exclusively for hay production, and an estimated $3.5 \mathrm{M}$ ha of lucerne is used in dryland farming operations (Pearson et al. 1997). There is potential for expansion of these dryland areas, with an additional estimated 86 and $9 \mathrm{M}$ ha suitable for planting in eastern and western Australia, respectively (Hill 1996). As well as the established uses of lucerne in hay or grazing operations, grazing lucerne is being used increasingly in conjunction with cereals for its capacity to increase soil nitrogen levels, improve water retention properties of soil, to reduce dryland salinity through lowering of the watertable, and to limit the deep drainage of water from soil profiles into river systems (Irwin et al. 2001).

All cultivated lucerne is autotetraploid $(2 n=4 x=32)$ (Stanford 1951), derived from either M. sativa subsp. sativa, or $M$. sativa subsp. sativa introgressed with $M$. sativa subsp. falcata. Most lucerne cultivars are genetically broad-based synthetics developed by randomly intermating elite $\mathrm{S}_{0}$ clones (genotypes) and advancing through several generations by open pollination (Busbice 1968; Hill et al. 1988). The breeding methodologies in lucerne, based on recurrent selection and polycrossing to produce synthetic varieties, have changed little over the last 60 years (Tysdal et al. 1942). Severe inbreeding depression has been a major issue that has limited the development of commercial lucerne hybrids (Bingham 1980), this being why the use of larger numbers of $\mathrm{S}_{0}$ clones, from 4 to $>100$, is favoured (Hill et al. 1988). In breeding synthetic lucerne cultivars, to maximise yield, every effort should be made to minimise inbreeding depression and to maximise heterozygosity and resultant heterosis (Bingham 1980; Brummer 1999). Kidwell et al. (1999) explored the use of neutral DNA markers to select genetically diverse parents to form synthetics where heterozygosity is maximised. Their studies indicated a lack of significant differences in forage yield between synthetics selected for random genetic dissimilarity or similarity, this being attributed to the inability to target heterozygosity to specific genomic regions affecting yield. Unfortunately, gains in lucerne yield have lagged far behind that realised in most 
other agronomic crops. Maize yield increases have been approximately $2 \%$ per year since the widespread adoption of single crosses (Duvick 1992), contrasting with lucerne yields, which have increased only $0.15-0.30 \%$ or less per year over the same time period (Brummer 1999). At least part of the cause of this slow gain is attributable to the complex genetic nature of lucerne. Another explanation for the yield stagnation is that breeding programs have focussed on increased pest resistance and other non-yield traits at the expense of breeding for yield. Maintaining or improving many different desirable traits has made concurrent yield improvement difficult (Hill et al. 1988).

Molecular markers for yield and other morphological traits will be valuable tools to lucerne improvement programs, if markers can be associated with these desirable traits in autotetraploid material. Genetic linkage maps have now been generated for a large number of diploid plant species, including diploid lucerne (Brummer et al. 1993; Kiss et al. 1993; Echt et al. 1994; Tavoletti et al. 1996; Barcaccia et al. 1999; Kaló et al. 2000). Three linkage maps of tetraploid lucerne have been published, the first being based on singledose restriction fragments (SDRFs) from restriction fragment length polymorphisms (RFLPs) (Brouwer and Osborn 1999), another generated with amplified fragment length polymorphism (AFLP) and simple sequence repeat (SSR) markers (Julier et al. 2003) and the third using random amplified polymorphic DNA (RAPD) and AFLP markers (Musial et al. 2005). In general, mapping studies in polyploid species are much less advanced, due to the more complex nature of polyploid inheritance patterns (Mather 1936; Fisher 1947). However the use of molecular markers to map yield and morphological traits in autotetraploid lucerne has considerable potential future benefit to lucerne improvement by breeding, particularly in overcoming the yield stagnation reported above.

There are no previous published reports where quantitative trait loci (QTL) conditioning yield in autotetraploid lucerne have been identified and genetically mapped. This paper reports the identification of QTL for yield, yield components, and morphological traits in an autotetraploid lucerne population, derived from winter-active parents adapted to northern Australia.

\section{Materials and methods}

\section{Plant materials}

The following clones and populations were used in the research and are as reported in Musial et al. (2005): D, a clone from cv. Demnat (Oram 1990) and previously determined in unpublished studies by the authors to be high yielding; W116, a clone from cv. Sequel (Oram 1990) and also previously determined in unpublished studies by the authors to be low to moderate in forage yield; WA401, a single $\mathrm{F}_{1}$ individual from the cross $(\mathrm{D} \times \mathrm{W} 116)$ and intermediate in yield to $\mathrm{D}$ and $\mathrm{W} 116$; $\mathrm{BC} 1$ to $\mathrm{BC} 136$, comprising 120 backcross (BC) individuals generated by crossing WA401 to D using suction emasculation. The $F_{1}$ individual (WA401) and each backcross individual were confirmed as resulting from a cross by studying the parents and their DNA banding patterns using RAPDs. All individual plants (D, W116, WA401, and BC individuals) were clonally propagated, as necessary, from stem cuttings. All plants were maintained in a glasshouse for 2 months until they were transplanted in the field in March 2002. The experiment was located on a welldrained black earth (Ug5.12, Northcote 1971) at Gatton Research Station, in south-eastern Queensland $\left(27^{\circ} 34^{\prime} \mathrm{S}, 152^{\circ} 20^{\prime} \mathrm{E}\right.$, alt. $\left.90 \mathrm{~m}\right)$, where Phytophthora root rot was known not to be an issue. Duplicates of the $120 \mathrm{BC}$ individuals were planted into a weed-free seedbed using a completely randomised design with no blocking. This was laid out in 80 rows, with 3 plants per row and $0.5 \mathrm{~m}$ separating individual plants. Plants were protected from anthracnose, caused by Colletotrichum trifolii, by bi-monthly application of Benlate (Dupont), a fungicidal spray.

\section{Agronomic determinations}

Table 1 lists the method applied to measuring each plant attribute to assess plant yield and morphological traits, where variation existed between D and W116. The experiment was harvested monthly from June to November 2002, a total of 6 times. The leaf-to-stem ratio (LSR) and leaf and stem yield per 5 stems were obtained by sampling leaves and stems from 5 randomly chosen stems per plant at the September 2002 harvest. Tiller number was assessed in May and July 2002; stem length was assessed at the July and October 2002 harvests. Leaf shape was assessed in October 2002

The Kolmogorov-Smirnov normality test confirmed that the data for each harvest, yield component, and morphological trait followed a normal distribution (data not shown). Correlations between the yield components and morphological traits were also made (MINITAB Release 13.20).

Segregation analysis, map construction, and QTL analysis

The methods used for the DNA extraction, and generation of the RAPD, AFLP, and SSR markers are those given in Musial et al. (2005).

RAPD, AFLP, and SSR markers that were present as a single band in D only, or were present in WA401 and D but absent from W116, were identified (Table 2). These markers were then assessed across the entire BC population of 120 individuals. This procedure allowed the development of a coupling phase map of markers located on the chromosomes of D. Expected segregations were 1:1 and 5:1 (for simplex and duplex markers, respectively, present in D only), and 3:1 (for simplex markers present in both D and WA401). Map construction was completed using Mapmaker version II for MacIntosh (Lander et al. 1987) as described in Musial et al. (2005). A genetic linkage map of parent W116, generated using the same approaches outlined here, has already been published (Musial et al. 2005).

QTL were identified with the program Map Manager QTXb20 (Manly et al. 2001) with $\alpha=0.05$ (probability of type I error). The regression analysis and interval mapping functions were applied. Markers with $P<0.01$ were used to indicate QTL that had a significant effect on the phenotype.

\section{Results}

Agronomic determinations

Traits assessed for D, W116, WA401, and the $120 \mathrm{BC}$ individuals, and the ranges of values obtained are given in Table 1. Figure 1 graphically represents the total yield for the $\mathrm{BC}$ population and also for each of the parentals (D, W116, and WA401). Highly significant positive correlations were evident between total yield and yield from harvest $1(r=0.549, P<0.001)$, harvest $2(r=0.734$, 
Table 1. Attributes measured on spaced plants of W116, D, and WA401 and their backcross population $((D \times$ W116 $) \times$ D) at Gatton, during the period April 2002 to April 2003, and the range of means observed for the parents and the backcross individuals

\begin{tabular}{|c|c|c|c|c|c|}
\hline Attribute & Measurement unit or rating & $\begin{array}{l}\text { Range of means } \\
\text { of } \mathrm{BC} \text { individuals }\end{array}$ & $\mathrm{D}$ & WA401 & W116 \\
\hline Total yield (H1-H6) & g DM per plant & $40.1-209.6$ & 213.6 & 134.4 & 100.5 \\
\hline Harvest 1 & g DM per plant & $1.8-19.0$ & 16.5 & 18.7 & 12.4 \\
\hline Harvest 2 & g DM per plant & $1.7-15.6$ & 12.9 & 8.1 & 7.9 \\
\hline Harvest 3 & g DM per plant & $4.6-32.8$ & 35.7 & 21.2 & 17.1 \\
\hline Harvest 4 & g DM per plant & $5.3-33.5$ & 35.9 & 17.7 & 10.2 \\
\hline Harvest 5 & g DM per plant & $4.1-40.6$ & 39.6 & 21.9 & 13.0 \\
\hline Harvest 6 & g DM per plant & $1.7-118.2$ & 73.1 & 46.8 & 40.1 \\
\hline Stem length 1 & $\mathrm{~cm}$, of length of longest stem & $20.0-42.3$ & 40.5 & 36.8 & 31.3 \\
\hline Stem length 2 & $\mathrm{~cm}$, of length of longest stem & $34.0-60.5$ & 56.0 & 50.0 & 45.5 \\
\hline Tiller No. 1 & Number per plant & $2.0-31.5$ & 17.0 & 19.5 & 15.0 \\
\hline Tiller No. 2 & Number per plant & $4.0-41.0$ & 20.5 & 21.5 & 25.0 \\
\hline Leaf shape & 1 , Narrow; 2 , medium; 3 , broadly round & $1.0-3.0$ & 2.0 & 1.5 & 1.5 \\
\hline Leaf yield/plant & g DM per plant & $2.7-18.7$ & 18.3 & 8.7 & 6.1 \\
\hline Stem yield/plant & g DM per plant & $2.2-16.7$ & 17.6 & 9.1 & 4.1 \\
\hline Leaf yield $/ 5$ stems & g DM per 5 stems & $1.0-3.5$ & 2.9 & 1.9 & 2.0 \\
\hline Stem yield $/ 5$ stems & g DM per 5 stems & $0.9-3.2$ & 2.8 & 2.2 & 1.4 \\
\hline Plant habit & 1 , Prostrate; 2 , semi-erect; 3 , erect & $1.0-3.0$ & 2.5 & 1.0 & 2.5 \\
\hline Percent leaf (LSR) & $\%$ & $41.2-64.2$ & 50.7 & 47.0 & 59.2 \\
\hline Pubescence & $\begin{array}{l}\text { 1, Few or no hairs on stems and upper leaf } \\
\text { surface; } 2 \text {, moderate hairiness; } 3 \text {, very hairy }\end{array}$ & $1.0-3.0$ & 1.5 & 1.0 & 1.5 \\
\hline
\end{tabular}

Table 2. Polymorphic markers used in the genetic analysis of yield, yield components, and plant morphology in the backcross population of $(\mathrm{D} \times \mathrm{W} 116) \times \mathrm{D}$

\begin{tabular}{lccc}
\hline \multicolumn{2}{c}{ Presence of marker in parents } & $\begin{array}{c}\text { Expected segregation } \\
\text { pattern }\end{array}$ \\
\hline W116 & D & WA401 & $1: 1$ \\
1 & 0 & 1 & $5: 1$ \\
0 & 0 & 1 & $1: 1$ \\
0 & 1 & 0 & $5: 1$ \\
0 & 1 & 0 & $3: 1$ \\
\hline
\end{tabular}

$P<0.001)$, harvest $3(r=0.826, P<0.001)$, harvest 4 $(r=0.875, P<0.001)$, harvest $5(r=0.899, P<0.001)$, and harvest $6(r=0.885, P<0.001)$ (Table 3$)$. The positive correlation between total yield and the individual harvest data strengthened as the plants became more established after transplanting. For total yield, WA401 was lower than mid-parent; the $\mathrm{BC}$ population ranged from much lower than $\mathrm{W} 116$ to as high yielding as D. There was also a moderate to strong positive correlation between total yield and stem length 1 ( $r=0.513, P<0.001)$, stem length $2(r=0.650$, $P<0.001)$, tiller number $1(r=0.352, P<0.001)$ and tiller number 2 ( $r=0.445, P<0.001)$, leaf yield $/$ plant $(r=0.884$, $P<0.001)$, leaf yield $/ 5$ stems $(r=0.545, P<0.001)$, stem yield/plant $(r=0.833, P<0.001)$, and stem yield $/ 5$ stems $(r=0.538, P<0.001)$. There was a weak positive correlation between total yield and plant habit $(r=0.287, P<0.01)$, and there was no correlation between total yield and either leaf shape or $\%$ leaf.

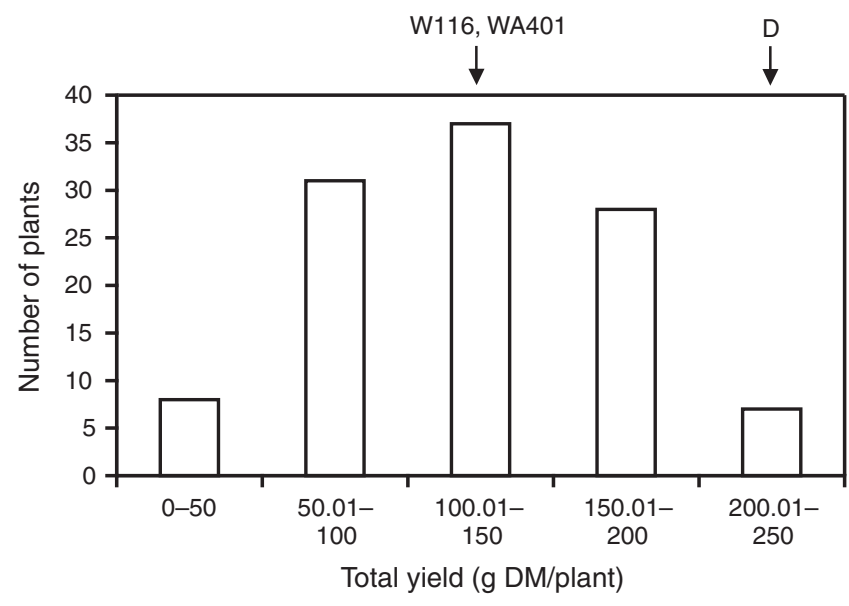

Fig. 1. Distribution of total yield (g DM/plant) in backcross individuals of the $(\mathrm{D} \times \mathrm{W} 116) \times \mathrm{D}$ mapping population. Yield of parents (W116 and D) and $F_{1}$ (WA401) is also indicated.

\section{QTL identified for yield, yield components, and morphological traits for W116}

Markers associated with yield at each individual harvest, and with total yield, were generated, and they showed a high degree of consistency between harvests (Table 4). The 10 markers associated with total yield at $P<0.01$ all had negative effects, contributing to a decrease in yield. Other yield components assessed included tiller number and stem length, which were measured twice during the experiment. Leaf and stem yield and leaf-to-stem ratio 


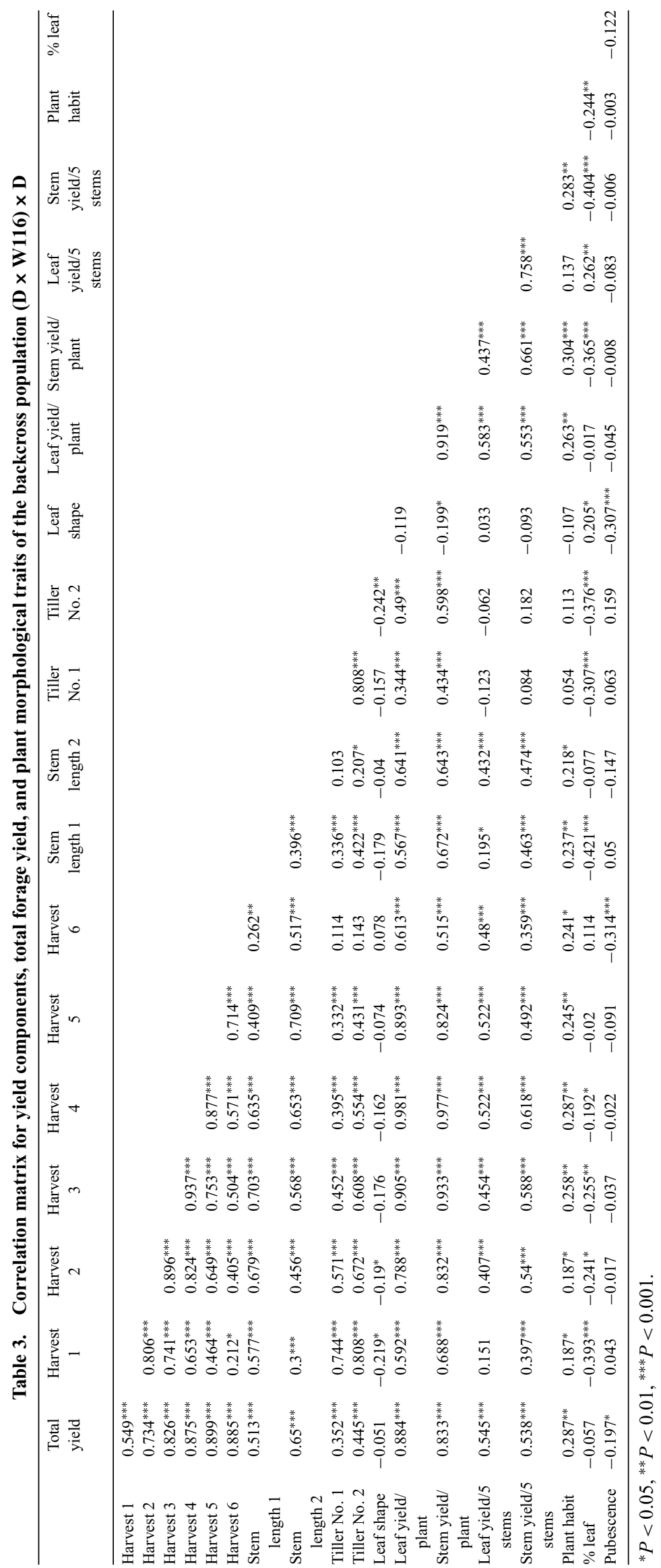


Table 4. Markers linked to quantitative trait loci (QTL) for yield, yield components, and morphological traits derived from clone W116 as identified in the backcross population $(\mathrm{D} \times \mathrm{W116}) \times \mathrm{D}$

\begin{tabular}{|c|c|c|c|c|c|c|c|c|c|c|c|}
\hline Trait & Group & Locus & $\begin{array}{c}\% \text { Total } \\
\text { variation }\end{array}$ & $P$ & $\begin{array}{l}\text { Additive } \\
\text { effects }\end{array}$ & Trait & Group & Locus & $\begin{array}{c}\text { \% Total } \\
\text { variation }\end{array}$ & $P$ & $\begin{array}{l}\text { Additive } \\
\text { effects }\end{array}$ \\
\hline \multirow[t]{10}{*}{ Total yield } & Unlinked & P3-2 & 7 & 0.00559 & -25.16 & & 9 & CC/AGG1 & 10 & 0.00175 & 17.40 \\
\hline & 2 & R5-1 & 9 & 0.00133 & -28.73 & & 13 & T19-1 & 9 & 0.00183 & -15.23 \\
\hline & 4 & $\mathrm{CG} / \mathrm{CT} 3$ & 6 & 0.00866 & -23.60 & Stem length 1 & Unlinked & U9-1 & 6 & 0.00708 & -2.51 \\
\hline & 4 & AC/TT4 & 7 & 0.00356 & -26.20 & & Unlinked & P3-2 & 19 & 0.00000 & -4.41 \\
\hline & 5 & $\mathrm{CA} / \mathrm{CG} 1$ & 7 & 0.00404 & -27.22 & & Unlinked & CC/CCA11 & 8 & 0.00313 & -3.10 \\
\hline & 5 & CG/CG10 & 9 & 0.00189 & -29.59 & & 2 & $\mathrm{C} 5-2$ & 7 & 0.00590 & -2.62 \\
\hline & 9 & $\mathrm{CC} / \mathrm{AGG} 1$ & 8 & 0.00712 & -22.07 & & 2 & U6-1 & 8 & 0.00208 & -2.84 \\
\hline & 10 & AC/TA8 & 8 & 0.00328 & -27.68 & & 11 & P11-1 & 6 & 0.00883 & -2.45 \\
\hline & 12 & AC/TT5 & 9 & 0.00192 & -30.22 & & 11 & AC6-1 & 6 & 0.00708 & -2.54 \\
\hline & 13 & T19-1 & 7 & 0.00587 & -24.87 & & 11 & D18-1 & 7 & 0.00485 & -2.66 \\
\hline \multirow[t]{4}{*}{ Harvest 1} & Unlinked & X3-1 & 8 & 0.00229 & 2.25 & & 11 & W17-1 & 8 & 0.00198 & -2.91 \\
\hline & Unlinked & P3-2 & 15 & 0.00003 & -3.06 & & 12 & AS9-1 & 7 & 0.00582 & -2.67 \\
\hline & 5 & CA/CG1 & 7 & 0.00761 & -2.03 & & 14 & AC/TG7 & 13 & 0.00021 & -3.58 \\
\hline & 12 & AS9-1 & 6 & 0.00879 & -2.02 & & 14 & S8-1 & 8 & 0.00185 & -2.90 \\
\hline \multirow[t]{9}{*}{ Harvest 2} & Unlinked & P3-2 & 12 & 0.00015 & -2.33 & & 14 & Y10-1 & 7 & 0.00574 & -2.66 \\
\hline & Unlinked & E3-1 & 7 & 0.00546 & -1.94 & & 14 & $\mathrm{CT} / \mathrm{CC} 8$ & 8 & 0.00495 & -2.91 \\
\hline & 2 & R5-1 & 6 & 0.00802 & -1.64 & & 15 & $\mathrm{CC} / \mathrm{TT} 8$ & 8 & 0.00415 & -2.95 \\
\hline & 5 & $\mathrm{CA} / \mathrm{CG} 1$ & 8 & 0.00286 & -1.94 & Stem length 2 & Unlinked & CC/ACA6 & 7 & 0.00535 & 2.86 \\
\hline & 5 & CG/CG10 & 9 & 0.00261 & -1.98 & & 2 & U6-1 & 7 & 0.00344 & -2.93 \\
\hline & 5 & AC/TT6 & 7 & 0.00770 & -1.77 & & 5 & CG/CG10 & 12 & 0.00030 & -3.81 \\
\hline & 12 & AS9-1 & 7 & 0.00472 & -1.81 & & 12 & AC/TT5 & 6 & 0.00962 & -2.80 \\
\hline & 14 & S8-1 & 6 & 0.00643 & -1.69 & & 14 & GC/CG2 & 7 & 0.00695 & -3.03 \\
\hline & 17 & CG/CG8 & 7 & 0.00867 & -1.86 & Tiller No. 1 & 12 & GC/CG5 & 9 & 0.00151 & -3.48 \\
\hline \multirow[t]{14}{*}{ Harvest 3} & Unlinked & P3-2 & 13 & 0.00015 & -5.32 & & 13 & GC/CG4 & 6 & 0.00939 & -2.79 \\
\hline & Unlinked & CC/CAA8 & 6 & 0.00906 & -3.57 & Tiller No. 2 & Unlinked & P3-2 & 11 & 0.00043 & -5.27 \\
\hline & Unlinked & CG/CG5 & 7 & 0.00738 & -3.87 & & Unlinked & X3-1 & 6 & 0.00792 & 3.88 \\
\hline & 2 & C5-2 & 6 & 0.00860 & -3.55 & & 5 & CA/CG1 & 9 & 0.00261 & -4.53 \\
\hline & 2 & R5-1 & 11 & 0.00034 & -4.69 & & 12 & GC/CG5 & 6 & 0.00695 & -4.08 \\
\hline & 2 & U6-1 & 7 & 0.00439 & -3.79 & Leaf shape & 3 & C5-1 & 7 & 0.00429 & 0.28 \\
\hline & 5 & $\mathrm{CA} / \mathrm{CG} 1$ & 9 & 0.00146 & -4.44 & & 3 & AC/TA6 & 14 & 0.00010 & 0.39 \\
\hline & 5 & $\mathrm{CG} / \mathrm{CG} 10$ & 10 & 0.00123 & -4.56 & & 3 & $\mathrm{CC} / \mathrm{TCC} 3$ & 12 & 0.00048 & 0.36 \\
\hline & 7 & CA/TG5 & 10 & 0.00570 & -4.86 & & 4 & AS11-1 & 7 & 0.00410 & -0.28 \\
\hline & 12 & AC/TT5 & 11 & 0.00073 & -4.85 & & 4 & J3-1 & 17 & 0.00001 & -0.42 \\
\hline & 12 & S13-1 & 6 & 0.00774 & -3.69 & & 4 & GC/TG3 & 14 & 0.00009 & -0.38 \\
\hline & 12 & AS9-1 & 7 & 0.00410 & -3.94 & & 4 & GC/TG5 & 11 & 0.00083 & -0.33 \\
\hline & 14 & AC/TG7 & 7 & 0.00500 & -3.86 & & 12 & AC/TT5 & 8 & 0.00293 & 0.30 \\
\hline & 14 & S8-1 & 7 & 0.00614 & -3.63 & & 18 & $\mathrm{CC} / \mathrm{CCA} 4$ & 10 & 0.00128 & 0.33 \\
\hline \multirow[t]{10}{*}{ Harvest 4} & Unlinked & P3-2 & 12 & 0.00021 & -5.11 & Leaf yield/plant & Unlinked & P3-2 & 9 & 0.00108 & -2.36 \\
\hline & 2 & $\mathrm{C} 5-2$ & 6 & 0.00736 & -3.79 & & 1 & AC/AGG2 & 6 & 0.00997 & -1.92 \\
\hline & 2 & R5-1 & 14 & 0.00006 & -5.46 & & 2 & R5-1 & 12 & 0.00015 & -2.69 \\
\hline & 2 & U6-1 & 12 & 0.00023 & -5.10 & & 2 & U6-1 & 10 & 0.00084 & -2.41 \\
\hline & 4 & AS11-1 & 6 & 0.00970 & -3.59 & & 4 & AS11-1 & 6 & 0.00730 & -1.93 \\
\hline & 5 & CA/CG1 & 9 & 0.00174 & -4.53 & & 4 & $\mathrm{CG} / \mathrm{CT} 3$ & 6 & 0.00867 & -1.89 \\
\hline & 5 & CG/CG10 & 11 & 0.00077 & -4.92 & & 4 & $\mathrm{AC} / \mathrm{TT} 4$ & 6 & 0.00842 & -1.90 \\
\hline & 7 & CA/TG5 & 14 & 0.00130 & -5.77 & & 5 & CA/CG1 & 7 & 0.00526 & -2.12 \\
\hline & 12 & AC/TT5 & 10 & 0.00142 & -4.76 & & 5 & CG/CG10 & 8 & 0.00295 & -2.28 \\
\hline & 14 & $\mathrm{AC} / \mathrm{TG} 7$ & 7 & 0.00715 & -3.86 & & 7 & CA/TG5 & 11 & 0.00334 & -2.82 \\
\hline \multirow[t]{15}{*}{ Harvest 5} & 2 & R5-1 & 8 & 0.00217 & -5.03 & & 12 & AC/TT5 & 9 & 0.00263 & -2.35 \\
\hline & 2 & U6-1 & 7 & 0.00364 & -4.85 & & 14 & $\mathrm{AC} / \mathrm{TG} 7$ & 8 & 0.00359 & -2.17 \\
\hline & 4 & CG/CT3 & 6 & 0.00885 & -4.31 & & 14 & AC/TA9 & 6 & 0.00862 & -1.89 \\
\hline & 4 & AC/TT4 & 10 & 0.00069 & -5.54 & Stem yield/plant & Unlinked & P3-2 & 15 & 0.00003 & -2.83 \\
\hline & 5 & $\mathrm{CA} / \mathrm{CG} 1$ & 9 & 0.00219 & -5.29 & & 2 & $\mathrm{C} 5-2$ & 7 & 0.00360 & -2.03 \\
\hline & 5 & $\mathrm{CG} / \mathrm{CG} 10$ & 11 & 0.00069 & -5.91 & & 2 & R5-1 & 13 & 0.00007 & -2.67 \\
\hline & 7 & CA/TG5 & 9 & 0.00907 & -5.49 & & 2 & U6-1 & 12 & 0.00020 & -2.55 \\
\hline & 9 & AC/TA3 & 7 & 0.00603 & -4.55 & & 5 & $\mathrm{CA} / \mathrm{CG} 1$ & 11 & 0.00070 & -2.41 \\
\hline & 9 & GC/TG2 & 6 & 0.00980 & -4.25 & & 5 & CG/CG10 & 12 & 0.00043 & -2.52 \\
\hline & 9 & CC/CCA9 & 6 & 0.00671 & -4.48 & & 7 & CA/TG5 & 15 & 0.00078 & -2.93 \\
\hline & 9 & F19-1 & 9 & 0.00103 & -5.35 & & 12 & $\mathrm{AC} / \mathrm{TT} 5$ & 10 & 0.00090 & -2.44 \\
\hline & 9 & CC/AGG1 & 10 & 0.00161 & -5.74 & Leaf yield $/ 5$ stems & Unlinked & CC/ACA6 & 7 & 0.00425 & 0.27 \\
\hline & 10 & AC/TA8 & 7 & 0.00529 & -4.82 & & Unlinked & $\mathrm{CG} / \mathrm{CG} 5$ & 8 & 0.00358 & -0.30 \\
\hline & 12 & AC/TT5 & 9 & 0.00173 & -5.57 & & 5 & AFct11-3 & 7 & 0.00683 & -0.21 \\
\hline & 12 & GC/CG5 & 6 & 0.00815 & -4.51 & & 5 & CG/CG10 & 7 & 0.00531 & -0.28 \\
\hline \multirow[t]{3}{*}{ Harvest 6} & Unlinked & V17-1 & 6 & 0.00859 & -13.74 & & 11 & H19-1 & 8 & 0.00352 & -0.27 \\
\hline & 4 & AC/TT4 & 6 & 0.00751 & -13.13 & & 13 & AC/AGG5 & 7 & 0.00779 & -0.26 \\
\hline & & & & & & & & & & \multicolumn{2}{|c|}{ (Continued next page) } \\
\hline
\end{tabular}


Table 4. Continued

\begin{tabular}{|c|c|c|c|c|c|c|c|c|c|c|c|}
\hline Trait & Group & Locus & $\begin{array}{c}\% \text { Total } \\
\text { variation }\end{array}$ & $P$ & $\begin{array}{l}\text { Additive } \\
\text { effects }\end{array}$ & Trait & Group & Locus & $\begin{array}{c}\% \text { Total } \\
\text { variation }\end{array}$ & $P$ & $\begin{array}{c}\text { Additive } \\
\text { effects }\end{array}$ \\
\hline \multirow{8}{*}{$\begin{array}{l}\text { Stem yield/ } \\
5 \text { stems }\end{array}$} & Unlinked & CC/ACA6 & 8 & 0.00320 & 0.27 & & 2 & U6-1 & 7 & 0.00550 & -0.29 \\
\hline & Unlinked & CG/CG5 & 8 & 0.00379 & -0.28 & & 13 & $\mathrm{CT} / \mathrm{CC} 3$ & 8 & 0.00724 & -0.30 \\
\hline & 2 & $\mathrm{C} 5-2$ & 8 & 0.00234 & -0.27 & $\%$ Leaf & Unlinked & P3-2 & 7 & 0.00465 & 2.38 \\
\hline & 2 & R5-1 & 10 & 0.00052 & -0.30 & & 1 & GC/TG1 & 7 & 0.00432 & -2.39 \\
\hline & 5 & $\mathrm{CG} / \mathrm{CG} 10$ & 8 & 0.00334 & -0.28 & & 3 & AC/TG10 & 7 & 0.00980 & 2.26 \\
\hline & 5 & AFct11-3 & 12 & 0.00025 & -0.26 & Pubescence & 3 & $\mathrm{CC} / \mathrm{TCC} 3$ & 12 & 0.00040 & -0.31 \\
\hline & 5 & AC/TT6 & 9 & 0.00250 & -0.29 & & 3 & AC/TA6 & 9 & 0.00260 & -0.27 \\
\hline & 12 & AC/TT5 & 7 & 0.00761 & -0.26 & & 3 & $\mathrm{~S} 12-2$ & 9 & 0.00097 & -0.29 \\
\hline \multirow[t]{2}{*}{ Plant habit } & Unlinked & $\mathrm{AC} / \mathrm{TT} 2$ & 7 & 0.00559 & 0.30 & & 12 & CT/GACC3 & 7 & 0.00993 & 0.25 \\
\hline & 2 & R5-1 & 7 & 0.00486 & -0.29 & & & & & & \\
\hline
\end{tabular}

were each measured once. Highly significant $(P<0.01)$ markers for these traits have been identified, and they almost always contributed negative additive effects, associated with a decrease in quanta for these traits, inherited from the parent W116 (Table 4).

In total, 16 QTL were identified for yield across all 6 harvests. Of these, 8 were identified in more than 1 harvest. They explained $6-15 \%$ of the phenotypic variation (Table 4 ). The QTL identified on linkage groups 2, 5, and 12 were the most consistently detected across the different harvests. An unlinked marker P3-2 identified the QTL with the largest effect and was also associated with 4 of the 6 harvests. In total, 10 QTL were identified for stem length, 3 of which were detected in both harvests (Table 4). Five of these had previously been identified for plant yield but a unique QTL on linkage group 11 , which explained $8 \%$ of the variation, was detected. Five QTL were detected for tiller number, all of which were previously detected for yield. Four of these QTL had a negative effect on the trait and only 1 of these QTL was consistent between harvests (Table 4). Four QTL were identified for leaf shape; the largest on linkage group 4 explained $17 \%$ of the variation. Two of the QTL had an effect on yield (Table 4). Twelve QTL were identified for leaf yield. Seven QTL were detected for stem yield and all of these had previously been detected with yield and stem length (Table 4). Three QTL were detected for plant habit. One on linkage group 2 had previously been detected with yield and the other 2 were unique to this trait. Percent leaf identified 3 QTL, 1 of which was unique to this trait (Table 4). The unlinked marker P3-2, which had a negative effect on yield and stem length, had a positive effect on \% leaf. Two QTL were identified for pubescence. The QTL identified on linkage group $12 \mathrm{had}$ a positive effect and explained $7 \%$ of the variation. The QTL on linkage group 3 had a negative effect on the trait and explained $12 \%$ of the variation; this same QTL had a positive effect on leaf shape (Table 4).

\section{QTL identified for yield, yield components,} and morphological traits for clone D

A linkage map was also constructed from bands present in D only and bands present in D and WA401 ( $F_{1}$ plant), generating a coupling map of the chromosomes contributed by clone D (Fig. 2). Due to the population structure, only a limited number of markers were polymorphic. This resulted in a linkage map with 8 linkage groups, which were generated using 52 RAPD, AFLP, and SSR markers; 16 markers remain unlinked. Polymorphisms were fewer than for W116 due to the nature of our mapping population, where backcross individuals contain $75 \%$ of the clone $\mathrm{D}$ genome. Since $\mathrm{D}$ is the higher yielding of the 2 parents, significant positive additive effects for yield were identified using D-specific markers. In total, 8 QTL were identified for yield for clone D across all 6 harvests (Table 5). Seven of these were detected in more than 1 dataset. The QTL identified on linkage group 2 with the largest positive effect on yield was detected at every harvest. This QTL explained up to $26 \%$ of the variation. Nine QTL were identified for stem length; 2 of these were detected in both datasets (Table 5). Four of these QTL also had an effect on yield and the largest effect was the QTL identified on linkage group 2. Two QTL were identified for tiller number, 1 with a positive effect and 1 with a negative effect. Both also had an effect on yield. Leaf yield identified 5 QTL all of which had previously been identified with yield. Again the largest effect QTL was on linkage group 2 (Table 5). Seven QTL were identified for stem yield, 6 of which had previously been identified for yield. One unique QTL was identified with the unlinked marker CC/TT14. For all these traits the QTL had a positive effect apart from 1 unlinked marker Z15-3, which had a consistently negative effect.

\section{Discussion}

This paper reports QTL associated with yield, yield components, and morphological traits of autotetraploid lucerne. QTL were identified in this winter-active germplasm, which had both positive and negative effects on yield, yield components, and morphological traits. Very few agronomic traits have been genetically mapped in autotetraploid lucerne. Brouwer etal. (2000) have identified QTL for winter hardiness, fall growth, and freezing injury in tetraploid lucerne. Obert et al. (2000) found AFLP markers associated with quantitatively expressed resistance to downy mildew in tetraploid lucerne, without generating a linkage map. Bouton (2004) outlines work being undertaken, but not yet published, 

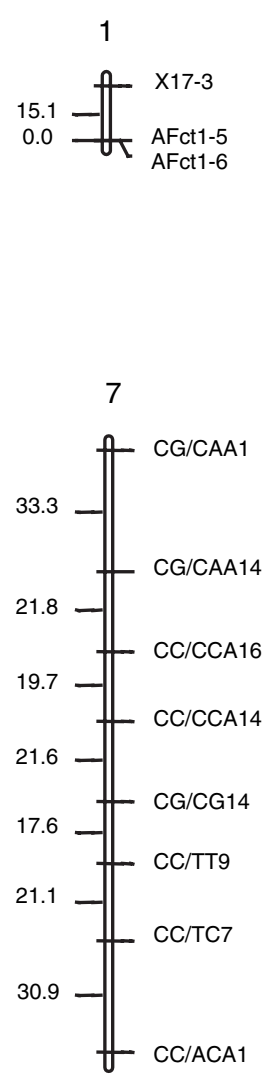

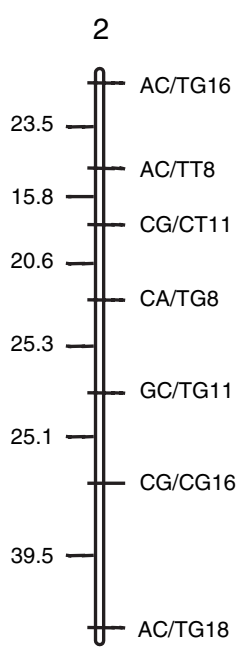

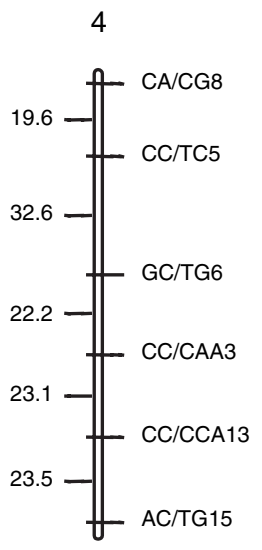

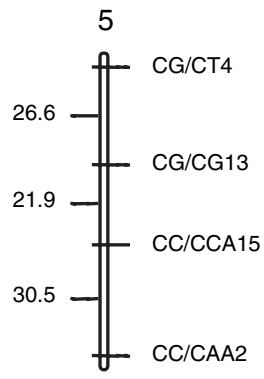

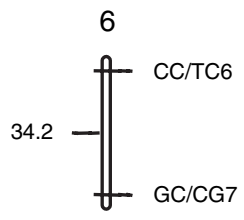

8

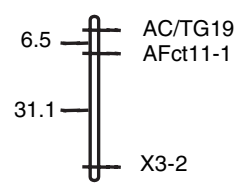

Fig. 2. A tetraploid lucerne (Medicago sativa) coupling phase linkage map generated from the backcross population $(\mathrm{D} \times \mathrm{W} 116) \times \mathrm{D}$ using random amplified polymorphic DNA (RAPD), amplified fragment length polymorphism (AFLP), and simple sequence repeat (SSR) markers. Bands present in D only and bands present in D and WA401 ( $\mathrm{F}_{1}$ individual) are mapped. Vertical bars represent the 8 linkage groups. Horizontal lines show marker positions. Genetic distances $(\mathrm{cM})$ are located to the left of the linkage groups and locus names are listed to the right.

to identify QTL and genes for yield in lucerne by a number of workers. The work presented here is the first world report of the identification of QTL for yield, yield components, and morphological traits in a winter-active, autotetraploid backcross population of lucerne.

Yield is one of the most important agronomic traits for forage crops (Riday and Brummer 2002). A strong positive correlation was evident between total yield, yield from individual harvests, stem length, tiller number, leaf and stem yield/plant, and leaf and stem yield/5 stems. This was reflected in the QTL identified on linkage groups 2, 4, and 8 from the D map (Fig. 2), which were consistently identified for each of these traits and they had positive additive effects contributing to increased yield. The QTL detected on linkage group 2 had a major effect on all the yield traits and explained a large amount of the phenotypic variation. This QTL has a similar effect to the major QTL identified in maize $T b 1$ (Lukens 1999). These results strongly indicate that rather than selecting only for yield per se, we can also select for yield components that are good predictors of increased yield. Such desirable agronomic traits identified in our winter-active population include stem length and tiller number. Volenec et al. (1987) described lucerne forage yield as the product of
3 components: plant density, tiller number, and shoot mass. Katepa-Mupondwa et al. (2002) also determined that stem length and stem yield were important determinants of dry matter yield in lucerne. It might have been anticipated that in more winter-dormant material, such as that used by Volenec et al. (1987) and Katepa-Mupondwa et al. (2002), the yield components we identified may not have been such good predictors of overall yield. Riday and Brummer (2002) also identified height and growth habit as important indicators of lucerne yield potential in winter-dormant germplasm, with an erect growth habit and taller height leading to increased overall yield. Burton (1937) examined the progeny of a cross between M. falcata and hairy Peruvian M. sativa genotypes. He found that height and leaf shape of the M. sativa $\times M$. falcata crosses were correlated with yield under field conditions. The issue of the utility of various yield components as predictors of overall yield in dormant and nondormant lucernes could perhaps be resolved experimentally, by conducting a similar experiment to the one described here, on a diallel of 2 non-dormant parents and 2 dormant parents, and testing the diallel populations in temperate and subtropical environments. The difference in height between D and W116 remained proportional for the 2 assessments 
Table 5. Markers linked to quantitative trait loci (QTL) for yield, yield components and morphological traits derived from clone D as identified in the backcross population $(\mathrm{D} \times \mathrm{W} 116) \times \mathrm{D}$

\begin{tabular}{|c|c|c|c|c|c|c|c|c|c|c|c|}
\hline Trait & Group & Locus & $\begin{array}{c}\text { \% Total } \\
\text { variation }\end{array}$ & $P$ & $\begin{array}{l}\text { Additive } \\
\text { effects }\end{array}$ & Trait & Group & Locus & $\begin{array}{c}\% \text { Total } \\
\text { variation }\end{array}$ & $P$ & $\begin{array}{l}\text { Additive } \\
\text { effects }\end{array}$ \\
\hline \multirow[t]{6}{*}{ Total yield } & Unlinked & AR1-2 & 7 & 0.00530 & 25.65 & Harvest 6 & 2 & AC/TT8 & 8 & 0.00528 & 15.61 \\
\hline & Unlinked & AC/AGG7 & 12 & 0.00062 & 33.66 & Stem length 1 & Unlinked & AC/TG14 & 10 & 0.00710 & 3.43 \\
\hline & 2 & AC/TG16 & 8 & 0.00531 & 32.07 & & Unlinked & $\mathrm{CC} / \mathrm{TT} 14$ & 7 & 0.00584 & 2.64 \\
\hline & 2 & AC/TT8 & 18 & 0.00001 & 44.30 & & Unlinked & AC/AGG7 & 13 & 0.00038 & 3.58 \\
\hline & 2 & CG/CT11 & 15 & 0.00002 & 39.63 & & 2 & $\mathrm{AC} / \mathrm{TG} 16$ & 20 & 0.00001 & 5.25 \\
\hline & 2 & GC/TG11 & 6 & 0.00809 & 24.51 & & 2 & $\mathrm{AC} / \mathrm{TT} 8$ & 23 & 0.00000 & 5.14 \\
\hline \multirow[t]{7}{*}{ Harvest 1} & Unlinked & Z15-3 & 8 & 0.00307 & -2.55 & & 7 & $\mathrm{CG} / \mathrm{CG} 14$ & 10 & 0.00112 & 4.45 \\
\hline & Unlinked & AR1-2 & 7 & 0.00497 & 2.13 & & 8 & AC/TG19 & 9 & 0.00113 & 3.06 \\
\hline & 2 & AC/TG16 & 7 & 0.00683 & 2.54 & & 8 & AFct11-1 & 9 & 0.00127 & 3.02 \\
\hline & 2 & AC/TT8 & 16 & 0.00003 & 3.37 & & 8 & X3-2 & 11 & 0.00031 & 3.32 \\
\hline & 2 & CG/CT11 & 16 & 0.00001 & 3.37 & Stem length 2 & 2 & AC/TG18 & 8 & 0.00421 & 2.92 \\
\hline & 2 & CA/TG8 & 6 & 0.00972 & 1.99 & & 2 & $\mathrm{AC} / \mathrm{TT} 8$ & 12 & 0.00040 & 3.96 \\
\hline & 2 & GC/TG11 & 9 & 0.00114 & 2.46 & & 2 & CG/CT11 & 13 & 0.00014 & 3.96 \\
\hline \multirow{9}{*}{ Harvest 2} & Unlinked & AC/AGG7 & 17 & 0.00002 & 2.82 & & 8 & X3-2 & 6 & 0.00687 & 2.72 \\
\hline & 2 & $\mathrm{AC} / \mathrm{TG} 18$ & 7 & 0.00568 & 1.74 & Tiller No. 2 & Unlinked & Z15-3 & 8 & 0.00224 & -5.17 \\
\hline & 2 & AC/TG16 & 12 & 0.00054 & 2.68 & & 2 & AC/TG16 & 8 & 0.00387 & 5.25 \\
\hline & 2 & AC/TT8 & 24 & 0.00000 & 3.51 & & 2 & $\mathrm{CG} / \mathrm{CT} 11$ & 6 & 0.00884 & 4.06 \\
\hline & 2 & CG/CT11 & 22 & 0.00000 & 3.22 & Leaf shape & 3 & U9-2 & 7 & 0.00551 & -0.30 \\
\hline & 2 & CA/TG8 & 7 & 0.00490 & 1.82 & Leaf yield/plant & Unlinked & AR1-2 & 12 & 0.00024 & 2.66 \\
\hline & 2 & GC/TG11 & 13 & 0.00012 & 2.40 & & Unlinked & AC/AGG7 & 11 & 0.00101 & 2.59 \\
\hline & 7 & $\mathrm{CG} / \mathrm{CAA} 1$ & 7 & 0.00503 & 2.12 & & 2 & AC/TG18 & 9 & 0.00145 & 2.40 \\
\hline & 8 & X3-2 & 12 & 0.00018 & 2.29 & & 2 & $\mathrm{AC} / \mathrm{TG} 16$ & 10 & 0.00156 & 2.91 \\
\hline \multirow[t]{5}{*}{ Harvest 3} & Unlinked & AR1-2 & 15 & 0.00002 & 5.60 & & 2 & AC/TT8 & 26 & 0.00000 & 4.20 \\
\hline & Unlinked & AC/AGG7 & 15 & 0.00010 & 5.62 & & 2 & $\mathrm{CG} / \mathrm{CT} 11$ & 23 & 0.00000 & 3.88 \\
\hline & 2 & AC/TG18 & 8 & 0.00344 & 4.06 & & 2 & CA/TG8 & 12 & 0.00028 & 2.73 \\
\hline & 2 & AC/TG16 & 12 & 0.00061 & 5.71 & & 2 & GC/TG11 & 12 & 0.00020 & 2.71 \\
\hline & 2 & AC/TT8 & 26 & 0.00000 & 7.86 & & 2 & CG/CG16 & 7 & 0.00399 & 2.09 \\
\hline \multirow{10}{*}{ Harvest 4} & Unlinked & AC/AGG7 & 11 & 0.00087 & 5.02 & & 2 & AC/TG16 & 13 & 0.00025 & 3.12 \\
\hline & 2 & AC/TG18 & 10 & 0.00086 & 4.82 & & 2 & AC/TT8 & 22 & 0.00000 & 3.68 \\
\hline & 2 & AC/TG16 & 13 & 0.00041 & 6.15 & & 2 & $\mathrm{CG} / \mathrm{CT} 11$ & 24 & 0.00000 & 3.73 \\
\hline & 2 & AC/TT8 & 25 & 0.00000 & 7.88 & & 2 & CA/TG8 & 10 & 0.00106 & 2.35 \\
\hline & 2 & $\mathrm{CG} / \mathrm{CT} 11$ & 24 & 0.00000 & 7.61 & & 2 & GC/TG11 & 15 & 0.00003 & 2.88 \\
\hline & 2 & CA/TG8 & 11 & 0.00045 & 5.07 & & 4 & $\mathrm{CA} / \mathrm{CG} 8$ & 10 & 0.00125 & 2.69 \\
\hline & 2 & GC/TG11 & 14 & 0.00007 & 5.55 & & 8 & X3-2 & 11 & 0.00025 & 2.48 \\
\hline & 2 & $\mathrm{CG} / \mathrm{CG} 16$ & 6 & 0.00799 & 3.72 & Leaf yield/5 stems & Unlinked & AC/AGG7 & 7 & 0.00974 & 0.27 \\
\hline & 4 & CA/CG8 & 13 & 0.00022 & 6.20 & & 2 & $\mathrm{AC} / \mathrm{TT} 8$ & 19 & 0.00001 & 0.47 \\
\hline & 8 & X3-2 & 12 & 0.00023 & 5.04 & & 2 & $\mathrm{CG} / \mathrm{CT} 11$ & 8 & 0.00222 & 0.30 \\
\hline \multirow[t]{9}{*}{ Harvest 5} & Unlinked & AR1-2 & 9 & 0.00105 & 5.47 & & 2 & GC/TG11 & 10 & 0.00083 & 0.32 \\
\hline & 2 & $\mathrm{AC} / \mathrm{TG} 18$ & 8 & 0.00250 & 5.20 & & 2 & CG/CG16 & 13 & 0.00009 & 0.36 \\
\hline & 2 & AC/TG16 & 7 & 0.00697 & 5.75 & & 4 & $\mathrm{CC} / \mathrm{TC} 5$ & 8 & 0.00292 & 0.40 \\
\hline & 2 & $\mathrm{AC} / \mathrm{TT} 8$ & 11 & 0.00055 & 6.41 & & 4 & $\mathrm{CA} / \mathrm{CG} 8$ & 13 & 0.00025 & 0.41 \\
\hline & 2 & CG/CT11 & 18 & 0.00000 & 7.87 & & 7 & CG/CAA14 & 9 & 0.00200 & 0.38 \\
\hline & 2 & CA/TG8 & 11 & 0.00039 & 6.15 & Stem yield/5 stems & Unlinked & Z15-3 & 10 & 0.00049 & -0.35 \\
\hline & 2 & GC/TG11 & 8 & 0.00316 & 4.97 & & Unlinked & AR1-2 & 10 & 0.00061 & 0.31 \\
\hline & 4 & CA/CG8 & 9 & 0.00213 & 6.24 & & Unlinked & $\mathrm{CC} / \mathrm{TT} 14$ & 14 & 0.00006 & 0.36 \\
\hline & 8 & X3-2 & 7 & 0.00441 & 4.68 & & 2 & AC/TG18 & 6 & 0.00937 & 0.24 \\
\hline
\end{tabular}


Table 5. Continued

\begin{tabular}{|c|c|c|c|c|c|c|c|c|c|c|c|}
\hline Trait & Group & Locus & $\begin{array}{c}\% \text { Total } \\
\text { variation }\end{array}$ & $P$ & $\begin{array}{l}\text { Additive } \\
\text { effects }\end{array}$ & Trait & Group & Locus & $\begin{array}{c}\% \text { Total } \\
\text { variation }\end{array}$ & $P$ & $\begin{array}{l}\text { Additive } \\
\text { effects }\end{array}$ \\
\hline & 2 & AC/TG16 & 9 & 0.00321 & 0.34 & & 4 & $\mathrm{CA} / \mathrm{CG} 8$ & 10 & 0.00161 & 0.34 \\
\hline & 2 & AC/TT8 & 18 & 0.00001 & 0.43 & & 7 & CG/CAA14 & 7 & 0.00656 & 0.31 \\
\hline & 2 & $\mathrm{CG} / \mathrm{CT} 11$ & 13 & 0.00008 & 0.36 & Plant habit & Unlinked & AR1-2 & 6 & 0.00715 & 0.28 \\
\hline & 2 & GC/TG11 & 17 & 0.00001 & 0.40 & & Unlinked & W11-3 & 7 & 0.00633 & -0.34 \\
\hline & 2 & CG/CG16 & 10 & 0.00056 & 0.30 & $\%$ Leaf & Unlinked & CC/TT14 & 6 & 0.00862 & -2.22 \\
\hline & 4 & CC/TC5 & 7 & 0.00618 & 0.35 & & 3 & U3-2 & 7 & 0.00701 & -2.61 \\
\hline
\end{tabular}

(June and October) of stem length, and both clones were taller at the October measurement. From this we can infer that the 2 clones had similar levels of winter activity.

The yield QTL we detected were identified from 6 harvests at Gatton Research Station, in subtropical south-eastern Queensland. These QTL may be unique indicators, specific for that location and climate. Yield was assessed in an artificially low-density population where individual plants were spaced $0.5 \mathrm{~m}$ apart. Therefore the QTL identified here may not be consistent with QTL important for forage yield under sward conditions, as it is known that wide spacing of plants permits greater tiller production (Berg et al. 2005). Riday and Brummer (2004) have experimentally demonstrated that yield heterosis expression in swards was lower than that in space-planted nurseries for M. sativa $\times$ M. falcata hybrids.

We detected QTL for increased yield on linkage groups 2, 4 , and 8 of the D map (Fig. 2). The QTL on linkage group 2 was the strongest, accounting for 6-26\% of the total variation. The QTL on linkage group 4 accounted for $8-13 \%$ of the total variation, and on linkage group $8,7-12 \%$ of the variation. Further saturation of the D map may result in detection of additional major QTL associated with increased yield and yield components. A major issue to be resolved is the utility of these yield and yield component QTL as indicators of highyielding genotypes in other genetic backgrounds. Given that they accounted for such a relatively high component of the phenotypic variation for yield, the testing in other winteractive clones would appear to be warranted. We are currently yield-testing $F_{1}$ populations derived from 2-clone crosses of at least 30 elite winter-active clones, which include D and W116. Work will be done to determine if there is an association between the presence of these QTL and yield in these populations. It is acknowledged however, that QTL markers such as we have identified may not have utility in allowing the identification of superior parental clones of a synthetic variety. This is because synthetic varieties are advanced for 2-3 generations by open pollination beyond the parental generation (Syn 0) (Fehr 1993). The QTL would have to be tracked through each of these generations to establish if they had a role in influencing yield of the final synthetic.

Detecting QTL for yield and yield components has provided a valuable set of markers having potential for breeders to use in the selection of improved lucerne genotypes. Markers linked to these QTL could be used directly to incorporate positive alleles and eliminate negative alleles of the yield components. The use of DNA markers in selection would allow the identification of potentially superior clones and the elimination of undesirable ones in early stages of a lucerne breeding program aimed at developing improved synthetics. Markers linked to some of the QTL we have identified are undergoing further study in validation and marker-assisted selection projects.

\section{Acknowledgments}

The authors thank the CRC for Tropical Plant Protection and GRDC (Grains Research and Development Corporation) for providing funding support for the project. We also thank Tom Bowdler, Jodie Smith, Nikki Casey, and David Armour for their assistance with maintenance, harvesting, and assessing the field experiment, and Dave Schofield and the staff at Gatton Research Station for the day-to-day management of the field experiment.

\section{References}

Barcaccia G, Albertini E, Tavoletti S, Falcinelli M, Veronesi F (1999) AFLP fingerprinting in Medicago spp.: Its development and application in linkage mapping. Plant Breeding 118, 335-340. doi: 10.1046/j.1439-0523.1999.00376.x

Berg WK, Cunningham SM, Brouder SM, Joern BC, Johnson KD, Santini J, Volenec JJ (2005) Influence of phosphorus and potassium on alfalfa yield and yield components. Crop Science 45, 297-304.

Bingham ET (1980) Maximizing heterozygosity in autotetraploids. In 'Polyploidy: biological relevance'. (Ed. WH Lewis) pp. 471-498. (Plenum Publishing Corporation: New York)

Bouton JH (2004) What is on the horizon for alfalfa and biotech. In 'Proceedings, National Alfalfa Symposium'. 13-15 December 2004, San Diego, CA. (UC Cooperative Extension, University of California: Davis, CA) (See http://alfalfa.ucdavis.edu)

Brouwer DJ, Duke SH, Osborn TC (2000) Mapping genetic factors associated with winter hardiness, fall growth and freezing injury in autotetraploid alfalfa. Crop Science 40, 1387-1396.

Brouwer DJ, Osborn TC (1999) A molecular marker linkage map of tetraploid alfalfa (Medicago sativa L.). Theoretical and Applied Genetics 99, 1194-1200. doi: 10.1007/s001220051324

Brummer EC (1999) Capturing heterosis in forage crop cultivar development. Crop Science 39, 943-954.

Brummer EC, Bouton JH, Kochert G (1993) Development of an RFLP map in diploid alfalfa. Theoretical and Applied Genetics $\mathbf{8 6}$, 329-332. doi: 10.1007/BF00222097 
Burton GW (1937) Alfalfa inheritance studies in New Jersey. Journal of Agronomy 29, 600-606.

Busbice TH (1968) Effects of inbreeding on fertility in Medicago sativa L. Crop Science 8, 231-234.

Duvick DN (1992) Genetic contributions to advances in yield of U.S. maize. Maydica 37, 69-79.

Echt CS, Kidwell KK, Knapp SJ, Osborn TC, McCoy TJ (1994) Linkage mapping in diploid alfalfa (Medicago sativa). Genome 37, 61-71.

Fehr WE (1993) 'Principles of cultivar development. Vol. 1: Theory and technique.' 536 pp. (Iowa State University: Ames, IA)

Fisher RA (1947) The theory of linkage in polysomic inheritance. Philosophical Transactions of the Royal Society of London 233, 55-87.

Hill MJ (1996) Potential adaptation zones for temperate pasture species as constrained by climate: a knowledge-based logical modelling approach. Australian Journal of Agricultural Research 47, 1095-1117. doi: 10.1071/AR9961095

Hill RR Jr, Shenk JS, Barnes RF (1988) Breeding for yield and quality. In 'Alfalfa and alfalfa improvement. Agronomy Monograph No. 29'. (Eds AA Hanson, DK Barnes, RR Hill Jr) pp. 809-826. (American Society of Agronomy, Crop Science Society of America, Soil Science Society of America: Madison, WI)

Irwin JAG, Lloyd DL, Lowe KF (2001) Lucerne biology and genetic improvement - an analysis of past activities and future goals in Australia. Australian Journal of Agricultural Research 52, 699-712. doi: 10.1071/AR00181

Julier B, Fajoulot S, Barre P, Cardinet G, Santoni S, Huguet T, Huyghe C (2003) Construction of two genetic linkage maps in cultivated tetraploid alfalfa (Medicago sativa) using microsatellite and AFLP markers. BMC Plant Biology 3, 9. doi: 10.1186/1471-2229-3-9

Kaló P, Endre G, Zimányi L, Csanádi G, Kiss GB (2000) Construction of an improved linkage map of diploid alfalfa (Medicago sativa). Theoretical and Applied Genetics 100, 641-657. doi: 10.1007/s001220051335

Katepa-Mupondwa FM, Christie BR, Michaels TE (2002) An improved breeding strategy for autotetraploid alfalfa (Medicago sativa L.). Euphytica 123, 139-146. doi: 10.1023/A:1014488307000

Kidwell KK, Hartweck LM, Yandell BS, Crump PM, Brummer JE, Moutray J, Osborn TC (1999) Forage yields of alfalfa populations derived from parents selected on the basis of molecular marker diversity. Crop Science 39, 223-227.

Kiss GB, Csanádi G, Kálmán K, Kaló P, Okrész L (1993) Construction of a basic genetic map for alfalfa using RFLP, RAPD, isozyme and morphological markers. Molecular and General Genetics 238, 129-137.

Lander ES, Green P, Abrahamson J, Barlow A, Daly MJ, Lincoln SE, Newburg L (1987) MapMaker: an interactive computer package for constructing primary genetic linkage maps of experimental and natural populations. Genomics 1, 174-181. doi: 10.1016/08887543(87)90010-3
Lukens L (1999) Epistatic and environmental interactions for quantitative trait loci involved in maize evolution. Genetical Research 74, 291-302. doi: 10.1017/S0016672399004073

Manly KF, Cudmore RH, Meer JM (2001) Map Manager QTX, crossplatform software for genetic mapping. Mammalian Genome 12, 930-932. doi: 10.1007/s00335-001-1016-3

Mather K (1936) Segregation and linkage in autotetraploids. Journal of Genetics 32, 287-314.

Michaud R, Lehman WF, Rumbaugh MD (1988) World distribution and historical development. In 'Alfalfa and alfalfa improvement. Agronomy Monograph No. 29'. (Eds AA Hanson, DK Barnes, RR Hill Jr) pp. 25-91. (American Society of Agronomy, Crop Science Society of America, Soil Science Society of America: Madison, WI)

Musial JM, Aitken KS, Mackie JM, Irwin JAG (2005) A genetic linkage map in autotetraploid lucerne adapted to northern Australia, and use of the map to identify DNA markers linked to resistance to Phytophthora medicaginis. Australian Journal of Agricultural Research 56, 333-344. doi: 10.1071/AR04317

Northcote KH (1971) 'A factual key for the recognition of Australian soils.' 3rd edn (Rellim Technical Publications: Glenside, S. Aust.)

Obert DE, Skinner DZ, Stuteville DL (2000) Association of AFLP markers with downy mildew resistance in autotetraploid alfalfa. Molecular Breeding 6, 287-294. doi: 10.1023/A:1009672008702

Oram RN (1990) 'Register of Australian herbage cultivars.' 3rd edn (CSIRO Publishing: Melbourne)

Pearson CJ, Brown R, Collins WJ, Archer KA, Wood MS, Petersen C, Boothe B (1997) An Australian temperate pastures database. Australian Journal of Agricultural Research 48, 453-465. doi: 10.1071/A96095

Riday H, Brummer EC (2002) Forage yield heterosis in alfalfa. Crop Science 42, 716-723.

Riday H, Brummer EC (2004) Performance of intersubspecific alfalfa hybrids in sward versus space planted plots. Euphytica 138, 107-112. doi: 10.1023/B:EUPH.0000046755.07566.c3

Stanford EH (1951) Tetrasomic inheritance in alfalfa. Agronomy Journal 43, 222-225.

Tavoletti S, Veronesi F, Osborn TC (1996) RFLP linkage map of an alfalfa meiotic mutant based on a $\mathrm{F}_{1}$ population. Journal of Heredity 87, 167-170.

Tysdal HM, Kiesselbach TA, Westover HL (1942) Alfalfa breeding. Nebraska Agricultural Experiment Station Research Bulletin 124

Volenec JJ, Cherney JH, Johnson KD (1987) Yield components, plant morphology, and forage quality of alfalfa as influenced by plant population. Crop Science 27, 321-326.

Manuscript received 9 November 2005, accepted 10 February 2006 